\title{
Soil fertility status, carbon and nitrogen stocks under cover crops and tillage regimes ${ }^{1}$
}

\author{
Fertilidade do solo, estoques de carbono e nitrogênio sob plantas de cobertura e \\ sistemas de manejo
}

\author{
Arminda Moreira de Carvalho², Robélio Leandro Marchão ${ }^{2 *}$, Kleberson Worslley $\operatorname{Souza}^{2}$ e Mercedes Maria da \\ Cunha Bustamante ${ }^{3}$
}

\begin{abstract}
The aim of the present study was to evaluate the effects of cover crops on the soil's chemical fertility, in particular its carbon and nitrogen content, in a Typic Acrustox under conventional and no-tillage corn systems. We hypothesized that the no-tillage system associates with cover crops maintains or increases soil carbon and nitrogen stocks and enhance soil fertility. The no-tillage system did not present higher carbon and nitrogen stocks than conventional tillage, but resulted in higher concentrations of exchangeable bases, higher CEC, and higher base saturation in the surface soil layer, mainly under use of Canavalia brasiliensis. Carbon and nitrogen stocks (up to $40 \mathrm{~cm}$ depth) differ significantly between the different cover crop species. The use of Mucuna pruriens and Canavalia brasiliensis allows maintain or increase soil $\mathrm{C}$ and $\mathrm{N}$ stocks. The no-tillage system results in higher accumulation of soil organic matter $(0-5 \mathrm{~cm})$, and appears very likely to enhance soil fertility. The use of Canavalia brasiliensis and Mucuna pruriens in succession to corn promotes carbon sequestration and can be used to enhance soil quality in Cerrado agroecosystems.
\end{abstract}

Key words: Brazilian Cerrado. No-tillage system. Ecological intensification. Low carbon agriculture.

RESUMO - O objetivo deste trabalho foi avaliar o efeito de diferentes plantas de cobertura sobre a fertilidade do solo, particularmente sobre os estoques de carbono e nitrogênio de um Latossolo Vermelho sob preparo convencional e Sistema Plantio Direto. Considerou-se a hipótese de que o Sistema Plantio Direto associado à utilização de plantas de cobertura promove uma manutenção ou incremento nos estoques de carbono e nitrogênio e melhora a fertilidade do solo. Não houve diferença significativa entre os estoques de carbono e nitrogênio entre os sistemas de preparo do solo, porém, o Sistema Plantio Direto apresentou maiores concentrações de bases trocáveis, maiores valores de CTC e saturação por bases na camada superficial do solo, principalmente na presença de Canavalia brasiliensis em sucessão ao milho. Os estoques de carbono e nitrogênio na camada de 0-40 cm diferiram significativamente na comparação entre plantas de cobertura e as espécies Mucuna pruriens e Canavalia brasiliensis foram as que apresentaram maiores valores de estoques de carbono e nitrogênio entre as espécies avaliadas. O uso do Sistema Plantio Direto resultou em acúmulo de matéria orgânica na camada 0-5 cm e promoveu melhoria na fertilidade do solo. A utilização das plantas de cobertura Canavalia brasiliensis ou Mucuna pruriens no Sistema Plantio Direto em sucessão ao milho é uma alternativa para o sequestro de carbono e melhoria da qualidade do solo no Cerrado.

Palavras-chave: Cerrado. Sistema plantio direto. Intensificação ecológica. Agricultura de baixa emissão de carbono.

\footnotetext{
*Autor para correspondência

${ }^{1}$ Recebido para publicação em 04/02/2014; aprovado em 22/08/2014

Trabalho financiado pela EMBRAPA e CNPq

${ }^{2}$ Embrapa Cerrados, BR 020, Km 18, Caixa Postal 08223, Planaltina-DF, Brasil, 73.310-970, arminda.carvalho@embrapa.br, robelio.marchao@ embrapa.br, kleberson.souza@embrapa.br

${ }^{3}$ Departamento de Ecologia, Universidade de Brasília, Asa Norte, Brasilia-DF, Brasil, 70.919-970, mercedes@unb.br
} 


\section{INTRODUCTION}

In the Savannas of Central Brazil, or Cerrado biome, the dominant soils are Latosols (Oxisols) and no-tillage systems were introduced in the mid-80s. However, the use of cover crops in these systems has been rarely studied. The no-till system (NTS) can increase soil organic carbon, total nitrogen and microbial biomass (MACHADO; SILVA, 2001; NGWIRA et al., 2012), fundamental components of soil fertility.

Modeling simulations for the Brazilian Cerrado indicated that soil $\mathrm{C}$ and $\mathrm{N}$ stocks under soybean monoculture with bare fallow declined approximately $20 \%$ after 50 years under no-tillage (CORBEELS et al., 2006). A more intensive agriculture combined with NTS practices can enhance C-accumulation rates by increasing biomass production whereby greater amounts of crop residues are returned to the soil (BATLLE-BAYER et al., 2010). Thus, simulated C and $\mathrm{N}$ stocks in cropping systems with two crops per year were comparable to those under native vegetation (BUSTAMANTE et al., 2006). The use of nitrogenfixing legumes (e.g. Crotalaria juncea L, and Mucuna pruriens (L) DC) as cover crops in agricultural systems can incorporate more than $200 \mathrm{~kg} \mathrm{~N} \mathrm{ha}^{-1}$ (CALEGARI et al., 2008). Zotarelli, et al. (2012) showed advantages of introducing legumes for green manuring as a means of replacing the $\mathrm{N}$ lost or removed in harvested grain as well as improving the residue quality to increase the efficiency of $\mathrm{N}$ fertilizer use.

Organic matter, which is present at medium levels ( 2 to $3 \mathrm{dag}^{-1}$ ) in these soils, is a fundamental component to regulate soil fertility. It is responsible for nutrient reserves, cycling and supply to the plants. The availability of phosphorus, that is one of the most limiting nutrients to the crops in the Cerrado soils, is directly related to the levels of organic matter in the soil (SOM). The $\mathrm{pH}$, the negative charges that result in the cation exchange capacity (CEC), and the aggregation that stabilizes the particles and reduces erosion are strongly associated with the SOM.

Some results obtained in no-tillage systems of the Brazilian Cerrado (CARVALHO et al., 2009; CARVALHO et al., 2011) showed that high lignin levels inhibit plant residue decomposition, promoting the establishment of soil cover, while lower levels of these compounds result in fast decomposition and thus faster nutrient cycling. The low concentrations of lignin present in Brachiaria ruziziensis which can accelerate plant residue decomposition, higher nutrient cycling and higher crop yields in succession (CARVALHO et al., 2011).
In the Cerrado region, crop rotations under no-tillage are mainly soybean as main crop followed by a cover crop such as pearl millet (Pennisetum glaucum), sorghum (Sorghum bicolor), or maize as the second commercial crop, from March to midJune (MALTAS et al., 2007). We hypothesized that the no-tillage and tillage systems with cover crops associates differ in their effects on soil fertility and $\mathrm{C}$ sequestrations due the dynamic of soil organic matter degradation. Thus the present study aimed to evaluate the effects of the use of cover crops on the chemical fertility and carbon and nitrogen stocks of a Typic Acrustox under maize cultivation in conventional and no-tillage systems.

\section{MATERIAL AND METHODS}

\section{Study area and experimental design}

The experiment was carried out in Planaltina, DF, Brazil, 15 ${ }^{\circ} 39^{\prime} \mathrm{S}$ and $47^{\circ} 44^{\prime} \mathrm{W}$, altitude of $1100 \mathrm{~m}$, on a plateau in the centre of the Cerrado region. The mean annual temperature is $26^{\circ} \mathrm{C}$, and during the study period, monthly precipitation ranged from nil (July 1997/2003) to 250-300 mm (January/December 1997/2003) with annual average rainfall of $1100 \mathrm{~mm}$. The monthly mean temperature oscillated between $19{ }^{\circ} \mathrm{C}$ (June 1997/2003) and $27{ }^{\circ} \mathrm{C}$ (March 1997/2003) (Figure 1).

The original vegetation, classified as Cerrado stricto sensu, was removed in 1975 and after corrective fertilization with lime and phosphate, was subjected to different land uses (crops, pasture and fallow) until the installation of the experiment. The experiment began in 1996 and the area was cultivated during six years with maize, in rotation with cover plants planted at the end of the rainy season, after harvesting the previous maize crop. The soil is a Typic Acrustox (SOIL SURVEY STAFF, 1998). The soil have a clay texture and shows little horizonation, a weak or no macrostructure and a strong microstructure with nearspherical microaggregates and originally very low natural nutrient content, low base saturation and high Al saturation.

In October 1996, before the establishment of the experiment, a soil sampling up to $20 \mathrm{~cm}$ was done aiming to characterize the initial chemical and physical properties of the experimental area, with composite samples by 20 sub samples per block (Table 1). The soil oxide concentration determined in a profile near from the experimental area and its relationships can be observed in the Table 2. 
Figure 1 - Average of temperature and precipitation during experimental period

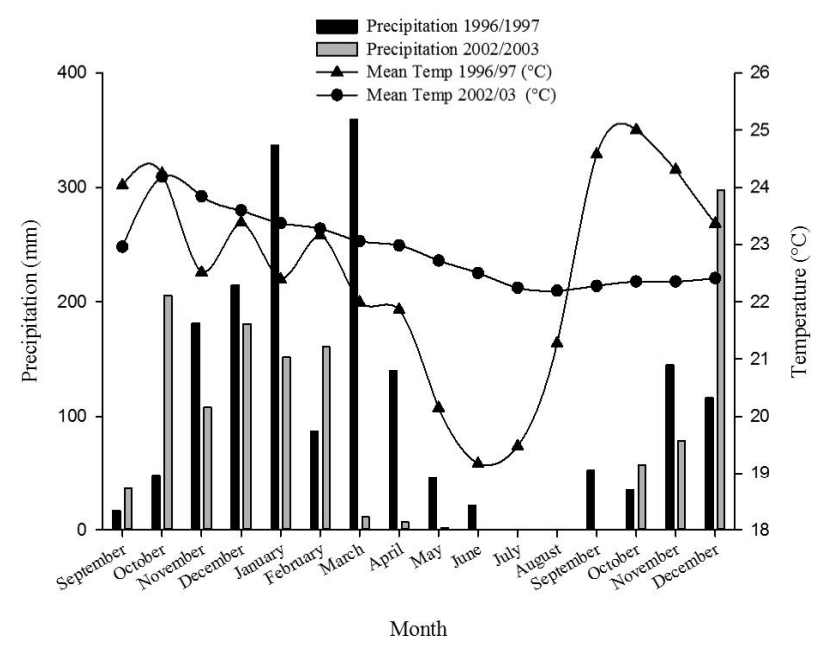

Table 1 - Soil physical and chemical attributes (mean of 20 samples) for the 0-20 cm depth of a Typic Acrustox, Planaltina$\underline{\text { Brazil }}$

\begin{tabular}{|c|c|}
\hline Attributes & Mean \\
\hline Clay $\left(\mathrm{g} \mathrm{kg}^{-1}\right)$ & 513 \\
\hline $\operatorname{Loam}\left(\mathrm{g} \mathrm{kg}^{-1}\right)$ & 186 \\
\hline Sand $\left(\mathrm{g} \mathrm{kg}^{-1}\right)$ & 301 \\
\hline $\mathrm{pH}\left(\mathrm{H}_{2} \mathrm{O}\right)$ & 6.2 \\
\hline Organic matter $\left(\mathrm{g} \mathrm{kg}^{-1}\right)$ & 23.6 \\
\hline $\mathrm{Al}\left(\mathrm{cmol}_{\mathrm{c}} \mathrm{kg}^{-1}\right)$ & 0.01 \\
\hline $\mathrm{H}+\mathrm{Al}\left(\mathrm{cmol}_{\mathrm{c}} \mathrm{kg}^{-1}\right)$ & 3.34 \\
\hline $\mathrm{Ca}^{2+}+\mathrm{Mg}^{2+}+\mathrm{K}^{+}\left(\mathrm{cmol}_{\mathrm{c}} \mathrm{kg}^{-1}\right)$ & 3.4 \\
\hline $\mathrm{Ca}^{2+}+\mathrm{Mg}^{2+}+\mathrm{K}^{+}+(\mathrm{H}+\mathrm{Al})\left(\mathrm{cmol}_{\mathrm{c}} \mathrm{kg}^{-1}\right)$ & 6.8 \\
\hline Base saturation $(\%)$ & 50 \\
\hline $\mathrm{P}\left(\mathrm{mg} \mathrm{kg}^{-1}\right)$ & 3.4 \\
\hline
\end{tabular}

Table 2 - Soil oxide concentrations and its molar relationships of a Typic Acrustox profile, Planaltina-Brazil

\begin{tabular}{|c|c|c|c|c|c|c|c|c|}
\hline \multirow{2}{*}{ Horizon } & \multirow{2}{*}{ Depth $(\mathrm{cm})$} & $\mathrm{Al}_{2} \mathrm{O}_{3}$ & $\mathrm{SiO}_{2}$ & $\mathrm{Fe}_{2} \mathrm{O}_{3}$ & $\mathrm{TiO}_{2}$ & \multirow{2}{*}{$\mathrm{Ki}$} & \multirow{2}{*}{$\mathrm{Kr}$} & \multirow{2}{*}{$\mathrm{Al}_{2} \mathrm{O}_{3} / \mathrm{Fe}_{2} \mathrm{O}$} \\
\hline & & -------- & $-\cdots$ & - & --------- & & & \\
\hline Ap & $0-30$ & 266 & 116 & 104 & 8.6 & 0.74 & 0.59 & 4.02 \\
\hline $\mathrm{AB}$ & -44 & 267 & 123 & 117 & 9.8 & 0.78 & 0.61 & 3.58 \\
\hline BA & -75 & 271 & 132 & 109 & 10.1 & 0.83 & 0.66 & 3.90 \\
\hline Bw1 & -151 & 290 & 131 & 124 & 10.4 & 0.77 & 0.60 & 3.67 \\
\hline Bw2 & -230 & 314 & 126 & 123 & 9.5 & 0.68 & 0.54 & 4.01 \\
\hline Bwf & $-230+$ & 280 & 134 & 111 & 10.2 & 0.81 & 0.65 & 3.96 \\
\hline
\end{tabular}

\section{Experimental field}

At the beginning of the experiment (January 1997), the area was fertilized with $180 \mathrm{~kg} \mathrm{ha}^{-1}$ of $\mathrm{P}_{2} \mathrm{O}_{5}$ as single superphosphate, $60 \mathrm{~kg} \mathrm{ha}^{-1}$ of $\mathrm{K}_{2} \mathrm{O}$ as potassium chloride, and $50 \mathrm{~kg} \mathrm{ha}^{-1}$ of micronutrients $\left(7 \mathrm{dag} \mathrm{kg}^{-1}\right.$ of $\mathrm{Zn}, 2.5 \mathrm{dag} \mathrm{kg}^{-1}$ of Bo, $1 \mathrm{dag} \mathrm{kg}^{-1}$ of $\mathrm{Cu}, 4 \mathrm{dag} \mathrm{kg}^{-1}$ of $\mathrm{Fe}, 4 \mathrm{dag} \mathrm{kg}^{-1}$ of Mn, $0.1 \mathrm{dag} \mathrm{kg}^{-1}$ of Mo, $0.1 \mathrm{dag} \mathrm{kg}^{-1}$ of Co). These fertilizers were incorporated to $20 \mathrm{~cm}$ using a disc plow and harrow in all experimental area.

The experimental design was a randomized complete blocks in a split plot arrangement with three replicates. Every year since 1997, cover crops were sown into whole plots $(12 \times 30 \mathrm{~m})$ in the end of each rainy season following a corn crop in both conventional tillage (with incorporation of plant residues using a disc plow and harrow) and no-tillage subplots, without incorporation of plant residues $(12 \times 15 \mathrm{~m})$. Plots and subplots were separated by $1 \mathrm{~m}$ border. Five hundred $\mathrm{kg} \mathrm{ha}^{-1}$ of gypsum were applied before the first corn crop and were incorporated with the plant residues using a disk harrow in subplots under conventional tillage or applied on the soil surface under no-tillage. The use of gypsum is recommended in highly weathered soils of the Cerrado region mainly to enhance leaching of calcium from the soil surface to the subsurface layers in the no-tillage system.

The following cover crop species were used in succession of corn: Canavalia brasiliensis $\mathrm{M}$. and Benth, Cajanus cajan (L.), Crotalaria juncea, Mucuna pruriens (Leguminosae), Pennisetum glaucum (Gramineae) and Raphanus sativus L (Brassicaceae). The control consisted of natural fallow, leaving only the plants sprouted spontaneously by natural seed bank soil. Every year cover crops were planted in March (end of rainy season). Seeds were sown $3 \mathrm{~cm}$ deep in $0.5 \mathrm{~m}$ wide rows using a no-tillage seeder. Plant population ranged between 8 (Mucuna pruriens) up to 40 (Raphanus sativus) plants per meter. 
Cover crops were cut when flowering reached approximately $50 \%$ and remained on the soil surface until sowing the corn at the beginning of the rainy season. In the no-tillage subplots, $3.0 \mathrm{~L} \mathrm{ha}^{-1}$ of glyphosate was applied to eliminate weeds and individuals of the cover species before sowing the corn. In the plots with Canavalia brasiliensis, a mixture of a mixture of $750 \mathrm{~g}^{\text {ai }} \mathrm{ha}^{-1}$ of glyphosate + 1,200 $\mathrm{g}_{\text {ai }} \mathrm{ha}^{-1}$ of 2.4-D (2-4 dichlorophenoxyacetic acid) was applied to eliminate weeds and plants that presented regrowth before sowing corn. In the conventional tillage subplots, plant residues were incorporated with a disc plough to $20 \mathrm{~cm}$ depth. Every year corn was sown at the beginning of the rainy season (typically in early November) at a density of 55,000 plants $\mathrm{ha}^{-1}$ and a $0.9 \mathrm{~m}$ inter-row spacing. At this time, $20 \mathrm{~kg} \mathrm{ha}^{-1}$ of $\mathrm{N}$ (urea), $150 \mathrm{~kg} \mathrm{ha}^{-1}$ of $\mathrm{P}_{2} \mathrm{O}_{5}$ and $80 \mathrm{~kg} \mathrm{ha}^{-1}$ of $\mathrm{K}_{2} \mathrm{O}$ were applied using the same implement. Additionally, $50 \mathrm{~kg} \mathrm{ha}^{-1}$ of $\mathrm{N}$ (urea) was sidedressed at the V-6 stage (defined as the emergence of the sixth pair of leaves). Nitrogen fertilization was repeated at the V-8 stage (defined as the emergence of the eighth pair of leaves), and at the silking stage, totaling $170 \mathrm{~kg} \mathrm{~N} \mathrm{ha}^{-1}$ topdressing.

\section{Soil sampling and analysis of soil fertility parameters}

Soil samples to characterize soil fertility parameters were collected in the 0-5 and 5-10 cm depths. The analysis of $\mathrm{pH}$ in water, $\mathrm{Ca}$ and $\mathrm{Mg}$ extracted with potassium chloride $(\mathrm{KCl}) 1 \mathrm{~mol} \mathrm{~L}^{-1}$, titratable acidity at $\mathrm{pH} 7,0$ extracted with calcium acetate $0,5 \mathrm{~mol} \mathrm{~L}^{-1} \mathrm{pH} 7,0$ $(\mathrm{H}+\mathrm{Al}), \mathrm{P}$ and $\mathrm{K}$ extractable by the Mehlich-1 method (hydrochloric acid 0,05 $\mathrm{N}$ and sulphuric acid 0,025 N) followed standard Embrapa (2009) procedures. The following soil fertility parameters were calculated: sum of bases $\left(\mathrm{S}=\mathrm{Ca}^{2+}+\mathrm{Mg}^{2+}+\mathrm{K}^{+}\right)$, cation exchange capacity (CEC), and percentage of bases saturation (BS).

\section{Soil sampling, $\mathrm{C}$ and $\mathrm{N}$ analysis and stocks calculations}

At the beginning of the experiment in October/ November 1996 a soil sampling was made to evaluate the initial organic matter contents. This sampling was made at 0 5, 5-10, 10-20, 20-30 and 30-40 cm depth intervals. Sampling was done in the 3 blocks totaling 16 subsamples per block and undisturbed samples were also taken in adjacent pits to characterize bulk density (Bd).

In September 2002, a second sampling (data presented in this paper) was done to evaluate the effects of cover crops and tillage regimes on $\mathrm{C}$ and $\mathrm{N}$ contents and stocks. Disturbed and undisturbed soil samples were collected in the subplots at a 0-5, 5-10, 10-20, 20-30 and 30-40 cm soil depth. In the 0-5 and 5-10 cm layers sampling was done in triplicate for disturbed samples and composite samples were obtained by mixing sub-samples. The disturbed soil samples were collected in two periods (dry and rainy season), perpendicularly to the corn sowing line. Sampling was also carried out in a reference area under native Cerrado vegetation (typical savannah) close to the experimental area. Undisturbed cores to calculate bulk density were collected using an Uhland sampler.

Soil organic carbon was measured by the wetoxidation method (WALKLEY; BLACK 1934) and converted to soil organic matter multiplying by 1,724 . To calculate carbon stocks, organic carbon contents measured by wet-oxidation were converted to total carbon using the model proposed by Sato et al. (2014) $\left(\mathrm{C}_{\mathrm{WB}}=\right.$ $\left.0.8411 \mathrm{C}_{\mathrm{CHNS} / \mathrm{O}}-3.8053\right)$. Total nitrogen was determined by sulfuric acid digestion using the Kjeldahl technique by steam distillation as described in Embrapa (1997).

Since there was no statistical difference between bulk densities (Table 3) for the cover crops effect, an equivalent depth approach was used to calculate $\mathrm{C}$ and

Table 3 - Bulk density under cover crops for different soil depths, Planaltina-Brazil

\begin{tabular}{|c|c|c|c|c|}
\hline \multirow{3}{*}{ Cover crops } & \multicolumn{4}{|c|}{ Bulk density $\left(\mathrm{g} \mathrm{dm}^{-3}\right)$} \\
\hline & \multicolumn{4}{|c|}{ Soil depth (cm) } \\
\hline & $0-5$ & $5-10$ & $10-20$ & $20-40$ \\
\hline Cajanus cajan & $0.82 \mathrm{a}^{*}$ & $0.88 \mathrm{a}$ & $1.13 \mathrm{a}$ & $1.11 \mathrm{a}$ \\
\hline Canavalia brasiliensis & $0.81 \mathrm{a}$ & $0.93 \mathrm{a}$ & $1.20 \mathrm{a}$ & $1.14 \mathrm{a}$ \\
\hline Crotalaria juncea & $0.80 \mathrm{a}$ & $0.89 \mathrm{a}$ & $1.13 \mathrm{a}$ & $1.11 \mathrm{a}$ \\
\hline Mucuna Pruriens & $0.80 \mathrm{a}$ & $0.92 \mathrm{a}$ & $1.20 \mathrm{a}$ & $1.14 \mathrm{a}$ \\
\hline Pennisetum glaucum & $0.87 \mathrm{a}$ & $0.94 \mathrm{a}$ & $1.17 \mathrm{a}$ & $1.07 \mathrm{a}$ \\
\hline Raphanus sativus & $0.87 \mathrm{a}$ & $0.93 \mathrm{a}$ & $1.18 \mathrm{a}$ & $1.09 \mathrm{a}$ \\
\hline Natural fallow & $0.85 \mathrm{a}$ & $0.90 \mathrm{a}$ & $1.15 \mathrm{a}$ & $1.05 \mathrm{a}$ \\
\hline
\end{tabular}

*Means in the same column followed by the same letter are not significantly different according to the Tukey test at $5 \%$ significance 
$\mathrm{N}$ stocks. Bulk density (Bd) was used to convert $\mathrm{C}$ and $\mathrm{N}$ concentrations $\left(\mathrm{g} \mathrm{kg}^{-1}\right)$ to mass per soil area $\left(\mathrm{Mg} \mathrm{ha}^{-1}\right)$ within a given soil depth using the expression:

C/N stocks $\left(M g h a^{-1}\right)=[C / N]\left(g_{k g}^{-1}\right) \times B d\left(g d m^{-3}\right) \times$ Soil depth $(m)$

To compare main effects (cover crops and tillage regimes) the sum of $0-40 \mathrm{~cm}$ soil layer was considered (with 0-5, 5-10, 10-20, 20-30 and 30-40 cm depth intervals).

\section{Statistical analysis}

An analysis of variance was applied considering repeated data over the time and space. The cover crops representing the main factor (plot), the residue management representing secondary factor (subplot), the space (subsubplot) is represented by different depth, the time (subsubsubplot) is represented by the different season (rain season and dry season). Thus the analysis of variance with repeated-measures (ANOVA) was applied to evaluate the effects of the four factors and all interactions between these factors, based on the split-plot design with repeated-measurements (COULTER et al., 2009). These analyses were performed using the SAS (Statistical Analysis System Institute) PROC MIXED procedure (SAS Institute 2000). Mean comparisons were made using the Tukey test at $5 \%$ significance level.

\section{RESULTS AND DISCUSSION}

\section{Soil organic matter and chemical properties}

The samples collected under the no-tillage system had higher mean soil organic matter values in the $0-5 \mathrm{~cm}$ soil layer $\left(3.5 \mathrm{dag}_{\mathrm{kg}}^{-1}\right)$ than in the conventional tillage $\left(3.0 \mathrm{dag} \mathrm{kg}^{-1}\right)$. The concentration of available phosphorus (Table 4) was higher on average in the soil samples under no-tillage (21 mg-P kg-1) than in the ones under conventional system $\left(17 \mathrm{mg}-\mathrm{P} \mathrm{kg}^{-1}\right)$ although it was not significant.

The accumulation of organic matter (Table 4) observed in the surface soil layer might have contributed to the increase in negative charge, and consequently, in the CEC (Table 5) in the soil surface $(0-5 \mathrm{~cm})$. The highest concentrations of exchangeable bases were found in the samples collected collected in the $0-5 \mathrm{~cm}$ soil layer $\left(\mathrm{S}=4.3 \mathrm{cmol}_{\mathrm{c}} \mathrm{kg}^{-1}\right)$ and in the rainy season $\left(\mathrm{S}=4.1 \mathrm{cmol}_{\mathrm{c}} \mathrm{kg}^{-1}\right)$, both under the no-tillage system (Table 3).

The samples collected under the conventional tillage had exchangeable bases (S) of $3.3 \mathrm{cmol}_{\mathrm{c}} \mathrm{kg}^{-1}$ and $3.1 \mathrm{cmol} \mathrm{kg}^{-1}$ in the $0-5 \mathrm{~cm}$ and $5-10 \mathrm{~cm}$ layers respectively. The cation exchange capacity (CEC) was higher (Table 5) in the soils under Crotalaria juncea (L) and Cajanus cajan (L), in the $0-5 \mathrm{~cm}$ layer under the conventional tillage $\left(\mathrm{CEC}=10.4\right.$ e $\left.9.0 \mathrm{cmol}_{\mathrm{c}} \mathrm{kg}^{-1}\right)$. Conventional tillage present CEC values of $8.7 \mathrm{cmol}_{\mathrm{c}} \mathrm{kg}^{-1}$ and $8.4 \mathrm{cmol}_{\mathrm{c}} \mathrm{kg}^{-1}$, in the $0-5 \mathrm{~cm}$ and $5-10 \mathrm{~cm}$ layers respectively. The base saturation (Table 5) was higher in the soil under Canavalia brasiliensis, under notillage $(\mathrm{V}=49 \%)$, than under conventional tillage (V $=38 \%$ ), in the rainy season. The samples collected in the $0-5 \mathrm{~cm}$ layer in the rainy season, in the no-tillage system, had higher average values of base saturation $(\mathrm{V}=50 \%)(\mathrm{p}>0.05)$.

\section{Carbon and nitrogen stocks}

Carbon stocks (up to $40 \mathrm{~cm}$ depth) differ significantly between the cover crop species but not between conventional and no-tillage systems (Table 6). Mucuna pruriens followed by Canavalia brasiliensis presents the higher carbon stocks. These two species and the natural fallow also resulted in the highest $\mathrm{N}$ stocks. The behavior of these species as regards the increases in $\mathrm{C}$ and $\mathrm{N}$ stocks in the soil was similar. In other words, the cover plants which resulted in higher stocks of $\mathrm{N}$ in the soil also stood out in relation to the stocks of $\mathrm{C}$.

Based on the data of $\mathrm{C}$ stocks in the adjacent native vegetation area $\left(81 \mathrm{Mg} \mathrm{C} \mathrm{ha-1}^{-1}\right)$, we observed a small increase in soil $\mathrm{C}$ stocks after deforestation and land use. This result is mainly due to the increase in bulk density values of the soil caused by land use (data not shown). The comparison of the actual results with the initial data of mean $\mathrm{C}$ stocks at the experiment implantation (88.2 $\mathrm{Mg} \mathrm{C} \mathrm{ha}^{-1}$ ) showed that only two cover crops, Mucuna pruriens and Canavalia brasiliensis, resulted in maintaining or increase soil carbon stocks with 88.9 and $88.4 \mathrm{Mg} \mathrm{C} \mathrm{ha}^{-1}$, respectively (Table 6). The highest values of $\mathrm{C}$ stocks shown in 1996, at the begin of the experiment, can be attributed to (i): the incorporation of the organic manure from native vegetation in the topsoil after deforestation; (ii) the corrective fertilization applied to cultivate the area during 20 years with different land uses (crops, pasture and fallow) until the installation of the experiment.

The accumulation of organic matter is one of the benefits of the no-tillage system, especially when it includes the use of cover crops such as legumes and tropical grasses, consequently higher nutrient cycling and higher crop yields in succession (CARVALHO et al., 2011, CARVALHO et al., 2012). Therefore, this practice will also promote effects in the concentrations of $\mathrm{C}, \mathrm{P}, \mathrm{K}, \mathrm{Ca}$ and Mg (BAYER et al., 2000; TIECHER et al., 2012). 
Table 4 - Soil chemical properties (organic matter, $\mathrm{pH}$, and $\mathrm{P}$ availability) under cover crops in conventional and no-tillage systems, Planaltina-DF, Brazil

\begin{tabular}{|c|c|c|c|c|c|c|c|c|}
\hline \multirow{4}{*}{ Main effect } & \multicolumn{4}{|c|}{ Soil organic matter } & \multicolumn{2}{|c|}{$\mathrm{pH}_{(\mathrm{H} 2 \mathrm{O})}$} & \multicolumn{2}{|c|}{$\mathrm{P}_{\text {Mehlich-1 }}$} \\
\hline & \multicolumn{2}{|c|}{$0-5 \mathrm{~cm}$} & \multicolumn{2}{|c|}{$5-10 \mathrm{~cm}$} & \multicolumn{4}{|c|}{ (mean among depths) } \\
\hline & $\mathrm{CT}^{\mathrm{a}}$ & $\mathrm{NTS}^{\mathrm{b}}$ & CT & NTS & \multirow{2}{*}{$\mathrm{CT}$} & \multirow{2}{*}{ NTS } & \multirow{2}{*}{$\mathrm{CT}$} & \multirow{2}{*}{ NTS } \\
\hline & \multicolumn{2}{|c|}{-------- dag kg-1 ------- } & \multicolumn{2}{|c|}{-------- $\mathrm{mg} \mathrm{kg}^{-1}$-------- } & & & & \\
\hline Crotalaria juncea & $3.0(\mathrm{a}) \mathrm{B}^{*}$ & 3.7 (a)A & 2.9 (a)A & $2.6(\mathrm{a}) \mathrm{A}$ & $5.4(\mathrm{a}) \mathrm{A}$ & $5.5(\mathrm{a}) \mathrm{A}$ & 22 & 16 \\
\hline Canavalia brasiliensis & $3.0(\mathrm{a}) \mathrm{B}$ & $3.6(\mathrm{ab}) \mathrm{A}$ & 2.9 (a)A & $2.7(\mathrm{a}) \mathrm{A}$ & $5.4(\mathrm{a}) \mathrm{B}$ & $5.6(\mathrm{a}) \mathrm{A}$ & 16 & 24 \\
\hline Cajanus cajan & $3.2(\mathrm{a}) \mathrm{A}$ & $3.5(\mathrm{ab}) \mathrm{A}$ & $2.8(\mathrm{a}) \mathrm{A}$ & 2.7 (a)A & $5.5(\mathrm{a}) \mathrm{A}$ & $5.5(\mathrm{a}) \mathrm{A}$ & 18 & 14 \\
\hline Pennisetum glaucum & 2.9 (a)B & $3.5(\mathrm{ab}) \mathrm{A}$ & $2.8(\mathrm{a}) \mathrm{A}$ & $2.5(\mathrm{a}) \mathrm{A}$ & $5.5(\mathrm{a}) \mathrm{A}$ & $5.5(\mathrm{a}) \mathrm{A}$ & 16 & 20 \\
\hline Mucuna pruriens & $3.0(\mathrm{a}) \mathrm{B}$ & $3.8(\mathrm{a}) \mathrm{A}$ & 2.7 (a)A & 2.7 (a)A & $5.4(\mathrm{a}) \mathrm{A}$ & 5.4(a)A & 15 & 20 \\
\hline Raphanus sativus & 2.9 (a)A & $3.2(\mathrm{~b}) \mathrm{A}$ & $2.8(\mathrm{a}) \mathrm{A}$ & $2.8(\mathrm{a}) \mathrm{A}$ & $5.5(\mathrm{a}) \mathrm{A}$ & 5.5 (a)A & 13 & 27 \\
\hline Natural fallow & 2.8 (a)B & $3.6(\mathrm{ab}) \mathrm{A}$ & 2.7 (a)A & $2.6(\mathrm{a}) \mathrm{A}$ & $5.5(\mathrm{a}) \mathrm{A}$ & 5.5 (a)A & 20 & 24 \\
\hline Mean & $3.0(\mathrm{~B})$ & $3.5(\mathrm{~A})$ & $2.8(\mathrm{~A})$ & $2.7(\mathrm{~A})$ & $5.5(\mathrm{~A})$ & $5.5(\mathrm{~A})$ & 17 (B) & $21(\mathrm{~A})$ \\
\hline
\end{tabular}

${ }^{a}$ Conventional tillage; ${ }^{b}$ No tillage system. *Means followed by different letters, lowercase on the column and uppercase on the line, differ according to the Tukey test at $5 \%$ significance

Table 5 - Soil chemical attributes (sum of bases - S, cation exchange capacity - CEC and base saturation - V) under cover crops in conventional and no-tillage systems, Planaltina-Brazil

\begin{tabular}{|c|c|c|c|c|c|c|c|c|c|c|}
\hline \multirow{4}{*}{$\frac{\text { Cover crops }}{\text { Crotalaria juncea }}$} & \multirow{2}{*}{\multicolumn{2}{|c|}{$\begin{array}{c}\mathrm{S} \\
\text { (mean of depths) } \\
\left(\mathrm{cmol}_{\mathrm{c}} \mathrm{kg}^{-1}\right)\end{array}$}} & \multicolumn{4}{|c|}{$\operatorname{CEC}\left(\mathrm{cmol}_{\mathrm{c}} \mathrm{kg}^{-1}\right)$} & \multicolumn{4}{|c|}{$\mathrm{V}$ (mean of depths) $(\%)$} \\
\hline & & & $0-5 \mathrm{~cm}$ & $5-10 \mathrm{~cm}$ & $0-5 \mathrm{~cm}$ & $5-10 \mathrm{~cm}$ & \multicolumn{2}{|c|}{ Rainy season } & \multicolumn{2}{|c|}{ Dry season } \\
\hline & $\mathrm{CT}^{\mathrm{a}}$ & $\mathrm{NTS}^{\mathrm{b}}$ & \multicolumn{2}{|c|}{$\mathrm{CT}$} & \multicolumn{2}{|c|}{ NTS } & $\mathrm{CT}$ & NTS & $\mathrm{CT}$ & NTS \\
\hline & $3.2 \mathrm{a}^{*}$ & $3.6 \mathrm{a}$ & $10.4(\mathrm{a}) \mathrm{A}^{*}$ & 8.5 (a)B & 9.1 (a)A & $8.6(a) A$ & 36 (a)A & 44 (a)A & 31 (a)A & 37 (a)A \\
\hline Canavalia brasiliensis & $3.1 \mathrm{a}$ & $4.0 \mathrm{a}$ & 8.3 (b)A & $8.6(\mathrm{a}) \mathrm{A}$ & 10 (a)A & 8.8 (a)B & 38 (a)B & 49 (a)A & 36 (a)A & 35 (a)A \\
\hline Cajanus cajan & $3.2 \mathrm{a}$ & $3.5 \mathrm{a}$ & $9.0(a b) A$ & $8.4(\mathrm{a}) \mathrm{A}$ & $8.8(\mathrm{a}) \mathrm{A}$ & 8.5 (a)A & 40 (a)A & 42 (a)A & 34 (a)A & 37 (a)A \\
\hline Pennisetum glaucum & $3.0 \mathrm{a}$ & $3.5 \mathrm{a}$ & $7.8(\mathrm{~b}) \mathrm{A}$ & 8.3 (a)A & $9.6(a) \mathrm{A}$ & 8.1 (a)A & 39 (a)A & 43 (a)A & 36 (a)A & 36 (a)A \\
\hline Mucuna pruriens & $3.2 \mathrm{a}$ & $3.4 \mathrm{a}$ & 8.7 (b)A & 8.3 (a)A & 9.7 (a)A & 8.5 (a)A & 40 (a)A & 42 (a)A & 37 (a)A & 32 (a)A \\
\hline Raphanus sativus & $3.0 \mathrm{a}$ & $3.3 \mathrm{a}$ & $8.0(\mathrm{~b}) \mathrm{A}$ & $8.1(\mathrm{a}) \mathrm{A}$ & $9.5(\mathrm{a}) \mathrm{A}$ & $8.4(\mathrm{a}) \mathrm{A}$ & 38 (a)A & 42 (a)A & 37 (a)A & 30 (a)A \\
\hline Natural fallow & $3.4 \mathrm{a}$ & $3.6 \mathrm{a}$ & 8.4 (b)A & 8.5 (a)A & 9.6 (a)A & 8.3 (a)A & 42 (a)A & 45 (a)A & 38 (a)A & 34 (a)A \\
\hline
\end{tabular}

${ }^{\mathrm{a} C}$ Conventional tillage; ${ }^{\mathrm{b}}$ No tillage system. No-Tillage System. Means followed by different letters, lowercase on the column and uppercase on the line, differ according to Tukey test at $5 \%$ significance

Table 6 - Carbon and nitrogen stocks under cover crops and in conventional and no-tillage systems, 0-40 cm depth, Planaltina-Brazil

\begin{tabular}{lcc}
\hline \multicolumn{1}{c}{ Cover crops } & C stocks $\left(\mathrm{Mg} \mathrm{ha}^{-1}\right)$ & $\mathrm{N} \mathrm{stocks}\left(\mathrm{Mg} \mathrm{ha}^{-1}\right)$ \\
\hline Cajanus cajan & $82.9(\mathrm{~b})^{*}$ & $5.9(\mathrm{ab})$ \\
Canavalia brasiliensis & $88.4(\mathrm{ab})$ & $6.2(\mathrm{a})$ \\
Crotalaria juncea & $83.7(\mathrm{ab})$ & $5.8(\mathrm{ab})$ \\
Mucuna Pruriens & $88.9(\mathrm{a})$ & $6.1(\mathrm{a})$ \\
Pennisetum glaucum & $84.3(\mathrm{ab})$ & $5.8(\mathrm{ab})$ \\
Raphanus sativus & $85.5(\mathrm{ab})$ & $5.6(\mathrm{~b})$ \\
Natural fallow & $85.0(\mathrm{ab})$ & $6.0(\mathrm{a})$ \\
\hline Tillage regimes & & \\
\hline Conventional tillage & $86.5(\mathrm{a})$ & $6.0(\mathrm{a})$ \\
No-tillage System & $84.5(\mathrm{a})$ & $5.9(\mathrm{a})$ \\
\hline
\end{tabular}

*Means in the same column followed by the same letter are not significantly different according to Tukey test at 5\% significance 
The high biomass production and nitrogen accumulation of Mucuna Pruriens and Canavalia brasiliensis and its accelerated decomposition (CARVALHO et al., 2009) could have contributed to the higher $\mathrm{C}$ stocks under the systems with these cover crops (Table 6). Also, the lower proportions of the recalcitrant aromatic $\mathrm{C}$ in Canavalia brasiliensis (CARVALHO et al., 2009) contributed to the faster decomposition of its residues (CARVALHO et al., 2011), resulting in the release of nutrients that, added to those from the fertilizer, resulted in a high sum of bases under no-tillage system (Table 5).

The faster release of nutrients during the decomposition of the plant residues of Canavalia brasiliensis (CARVALHO et al., 2011), mainly the nitrogen and phosphorus which are limiting in the soils of Cerrado, contributed to the higher yield of the corn crop following this cover crop (CARVALHO et al., 2012). The corn yield was higher following Canavalia brasiliensis than after Raphanus sativus.

Soil C stocks are a function of $\mathrm{C}$ and $\mathrm{N}$ inputs and the chemical composition of plant tissues and decomposition, microbial biomass and activity, management practices, and soil and climatic factors (CARVALHO et al., 2011). Regardless of the soil management practice, winter fallow stored the smallest amount of organic $\mathrm{C}$ in all the soil depths tested $(0-5,5-10,10-20,20-40 \mathrm{~cm})$. The inclusion of cover crops in no-tillage systems is probably the single most likely explanation of the success of such systems in Brazil and other South American countries. The role of nitrogen input in increasing the potential carbon sequestration in tropical soils has been investigated recently. Leguminous cover crops play an important role as a source of nitrogen, with positive effects on carbon sequestration (BAYER et al., 2006).

The results reveal the importance of diversification of soil cover rotation in intense crop cultivation systems in order to maintain soil carbon and nitrogen levels. The chemical composition of different cover crops with appropriate $\mathrm{C}: \mathrm{N}$ and $\mathrm{C}: \mathrm{P}$ ratios is fundamental to the carbon sequestration in the soil under systems using cover crop rotations in the Cerrado region (CARVALHO et al., 2009; CARVALHO et al., 2011; CARVALHO et al., 2012).

The no-tillage system appears very likely to enhance soil fertility, and thus to increase crop yields. The use of cover crops during five years shown significant carbon sequestration, and the use of Canavalia brasiliensis and Mucuna pruriens in succession with maize allows increase or maintain soil $\mathrm{C}$ stocks. The results illustrate the importance of cover crops diversification (ecological intensification) in intense crop cultivation systems to maintain soil fertility and sustainability in agroecosystems.

\section{CONCLUSION}

There were significant differences in the carbon and nitrogen stocks between the different cover crops grown in succession to maize after five years of cultivation. The use of Mucuna pruriens and Canavalia brasiliensis allows maintain or increase soil C stocks, giving an average value of $88.6 \mathrm{Mg} \mathrm{C} \mathrm{ha}^{-1}$ close to the initial condition of the experiment. The no-tillage system results in higher accumulation of soil organic matter $(0-5 \mathrm{~cm})$, and appears very likely to enhance soil fertility. The use of Canavalia brasiliensis and Mucuna pruriens alson resulted in the higher N stocks in the soil. These results illustrate the importance of soil cover diversification in intense crop cultivation systems to maintain soil fertility and carbon sequestration in Cerrado agroecosystems.

\section{ACKNOWLEDGEMENTS}

We would like to thank $\mathrm{CNPq}$ and CAPES/ EMBRAPA funding, for granting a fellowship to Arminda Moreira de Carvalho and Kleberson Worslley Souza, respectively.

\section{REFERENCES}

BATLLE-BAYER, L.; BATJES, N. H.; BINDRABAN, P. S. Changes in organic carbon stocks upon land use conversion in the Brazilian Cerrado: A review. Agriculture Ecossystem Environment, v. 137, n. 1-2, p. 47-58, 2010.

BAYER, C. et al. A method for estimating coefficients of soil organic matter dynamics based on long-term experiments. Soil \& Tillage Research, v. 91, n. 1-2, p. 217-226, 2006.

BAYER, C. et al. Organic matter storage in a sandy clay loam Acrisol affected by tillage and cropping systems in southern Brazil. Soil \& Tillage Research v. 54, p. 101-109, 2000 .

BUSTAMANTE, M. M. C. et al. Soil carbon and sequestration potential in the Cerrado Region of Brazil. In: Lal R, Cerri CC, Bernoux M, Etchevers J, Cerri CEP (Eds) Carbon sequestration in soils of Latin America. 1. ed. New York: Food Product Press, 2006, cap. 14, p. 285-304.

CALEGARI, A. et al. Impact of long-term no-tillage and cropping system management on soil organic carbon in an Oxisol: a model for sustainability. Agronomy Journal, v. 100, n. 4, p. 1013-1020, 2008.

CARVAlHO, A. M. et al. Chemical composition of cover plants and its effect on maize yield in no-tillage systems in the Brazilian savanna. Crop \& Pasture Science, v. 63 n. 12, p. 1075-1081, 2012. 
CARVAlHO, A. M. et al. Characterization by solid-state CPMAS 13C NMR spectroscopy of decomposing plant residues in conventional and no-tillage systems in Central Brazil. Soil \& Tillage Research, v. 101, n. 1, p. 100-107, 2009.

CARVALHO, A. M. et al. Cover plants with potential use for crop-livestock integrated systems in the Cerrado region. Pesquisa Agropecuária Brasileira, v. 46, n. 10, p. 12001205, 2001.

COULTER, J. A.; NAFZIGER, E. D.; WANDER, M. Soil organic matter response to cropping system and nitrogen fertilization. Agronomy Journal, v. 101, n. 3, p. 592-599, 2009.

CORBEELS, M. et al. Soil carbon storage potential of direct seeding mulch-based cropping systems in the Cerrados of Brazil. Global Change Biology, v. 12, n. 9, p. 1773-1787, 2006.

EMPRESA BRASILEIRA DE PESQUISA AGROPECUÁRIA. Manual de métodos de análise de solo. 2.ed. Rio de Janeiro: Centro Nacional de Pesquisa de Solos, 2009. 627 p.

EMPRESA BRASILEIRA DE PESQUISA AGROPECUÁRIA. Sistema Brasileiro de Classificação de solos. 3. ed. Rio de Janeiro: Centro Nacional de Pesquisa de Solos, 2013. 353 p.

MACHADO, P. L. O. A.; SILVA, C. A.; Soil management under no-tillage systems in the tropics with special reference to Brazil. Nutrient Cycle in Agroecosystem v. 61, n. 1-2, p. 119-130, 2001.

MALTAS, A. et al. Long-term effects of continuous direct seeding mulch-based cropping systems on soil nitrogen supply in the Cerrado region of Brazil. Plant and Soil, v. 298, n. 1-2, p. 161-173, 2007.

NGWIRA, A.; SLEUTEL, S.; NEVE, S. Soil carbon dynamics as influenced by tillage and crop residue management in loamy sand and sandy loam soils under smallholder farmers conditions in Malawi. Nutrient Cycling in Agroecosystem, v. 92 , n. 3 , p. $315-328,2012$.

SAS INSTITUTE INC., System for Microsoft Windows. Release 8.01. Cary: NC, USA, CD-Rom, 2001.

SATO, J. H. et al. Methods of soil organic carbon determination in Brazilian savannah soils. Scientia Agricola, v. 71, n. 4, p. 302-308, 2014.

SOIL SURVEY STAFF. Keys to Soil Taxonomy. 11. ed. United States, Washington: Department of Agriculture, Natural Resources Conservation Service, 2010.

TIECHER, T.; RHEINHEIMER, D. S.; CALEGARI, A. Soil organic phosphorus forms under different soil management systems and winter crops, in a long term experiment. Soil \& Tillage Research, v. 124, n. 1, 57-67, 2012.

WALKLEY, A.; BLACK, I. A. An examination of the Degtjareff method for determining soil organic matter and a proposed modification of the chromic acid titration method. Soil Science, v. 37, n. 1, p. 29-38, 1934.

ZOTARELLI, L. et al. Influence of no-tillage and frequency of a green manure legume in crop rotations for balancing $\mathrm{N}$ outputs and preserving soil organic C stocks. Field \& Crops Research, v.132, especial issue, p. 185-195. 